\title{
Zadowolenie z życia w kontekście perspektyw czasowych i struktury wartości - porównanie międzykulturowe studentów z Polski i Ugandy
}

\begin{abstract}
Research problem: The focus of the research was to determine the differences and connections in subjective well-being, time perspective and values among groups from various cultures and socio-economic status. The samples of Polish and Ugandan population, which are highly diverse geographically, socially, economically and culturally, were examined and compared in the study. Participants: The Polish data were collected from 58 management students (45 F, 13 M) from Jagiellonian University in Krakow; mean age $M=20.21$ years old, $S D=1.10$. The Ugandan data were collected from 47 management students (28 F, $19 \mathrm{M}$ ) in similar age from Makerere University in Kampala and Fort Portal. Measures: Respondents from Uganda completed the Subjective Well-Being Scale (SWLS) by Diener, the Zimbardo Time Perspective Inventory (ZTPI) and the Portrait Values Questionnaire (PVQ) by Schwartz. The original versions of methods, written in English (which is official language in Uganda) were
\end{abstract}

1 Józef Maciuszek, Instytut Psychologii Stosowanej, Uniwersytet Jagielloński w Krakowie, Polska, jozef.maciuszek@uj.edu.pl.

2 Kinga Tucholska, Instytut Psychologii Stosowanej, Uniwersytet Jagielloński w Krakowie, Polska, kinga.tucholska@uj.edu.pl.

3 Anna Kawula, Katedra Pedagogiki Społecznej i Andragogiki, Instytut Nauk o Wychowaniu, Uniwersytet Pedagogiczny w Krakowie, Polska, kawula.anna@gmail.com. 
used. In Poland were used version of SWLS adapted by Juczyński, ZTPI adapted by Cybis, Rowiński and Przepiórka, and Polish version of PVQ adapted by Cieciuch and Zaleski. Results: Statistical analysis carried out on Polish and Ugandan sample survey data revealed statistically significant differences in time perspective and in basic personal values, but not in subjective well-being. The results were interpreted in the context of specific social, economic, and cultural conditions and discussed with reference to previous findings.

\section{Key words:}

satisfaction with life, time perspective, values, cross-cultural comparisons, students

\section{WPROWADZENIE}

Istnieje wiele sposobów rozumienia i badania jakości życia. Podstawowe dwa podejścia zakładają ujmowanie jakości życia w sensie obiektywnym albo w sensie subiektywnym (fenomenalistycznym), co wyznacza różne sposoby podejścia badawczego i rodzaj przyjmowanych wskaźników pomiaru. Wskaźniki obiektywne odnoszą się do warunków życia i ekonomicznego dobrobytu (należy do nich na przykład HDI - Human Development Index). Fenomenalistyczne koncepcje jakości życia wiążą tę jakość z dobrostanem psychicznym, z subiektywnym poczuciem zadowolenia, szczęściem, poczuciem sensu, akceptacją wartości własnego życia. Takie podejście odwołuje się do jednego z podstawowych sposobów rozumienia szczęścia w tradycji filozoficznej - jako pełnego i trwałego zadowolenia z całości życia, zadowolenia zarówno o charakterze emocjonalnym, jak i intelektualnym. Na tak rozumiane szczęście składa się zarówno radość z życia (cieszenie się nim), jak i dodatnia ocena, aprobowanie go (Tatarkiewicz, 2012).

Dobrostan psychiczny (ang. subjective well-being, SWB) jest ujmowany jako emocjonalna i poznawcza ocena własnego życia, czyli doświadczanie przyjemnych emocji przy niskim poziomie negatywnych nastrojów oraz wysoki poziom zadowolenia z życia (Diener, Lucas, Oishi, 2004; Triandis, 2004). Innymi słowy, dobrostan w perspektywie poznawczej oznacza zadowolenie z całości życia, a w perspektywie emocjonalnej - częstotliwość i intensywność doświadczania pozytywnych i negatywnych emocji. W tym ujęciu szczęście wiązane jest z emocjonalnym składnikiem dobrostanu, a zadowolenie, satysfakcja - ze składnikiem poznawczym dobrostanu psychicznego. 
Do ważnych kwestii dyskutowanych przez badaczy należy pytanie o rolę obiektywnych warunków życia w doświadczaniu dobrostanu psychicznego (Maciuszek, 2014). Ich ważność jest na przykład podkreślana w teorii potrzeb sformułowanej przez Veenhovena (Hagerty, Veenhoven, 2003), gdzie łączy się poziom szczęścia z zaspokojeniem potrzeb biologicznych i psychicznych. W takim ujęciu zasobność finansowa, która umożliwia zaspokojenie wielu potrzeb, byłaby głównym predyktorem doświadczenia szczęścia. Jednak większość wyników badań empirycznych (Diener i in., 2004) nie potwierdza istnienia prostego związku między posiadanym majątkiem i warunkami życia a dobrostanem psychicznym. Okazuje się, że zależność między nimi słabnie, gdy zaspokojone są potrzeby niższego rzędu. Jak zauważa Diener: „wydaje się, że sposób postrzegania świata ma o wiele większy wpływ na poczucie szczęścia niż obiektywne warunki [...] Odpowiedź na pytanie, czy poszczególne czynniki demograficzne zwiększają dobrostan psychiczny, zależeć będzie od wyznawanych przez ludzi wartości, ich celów życiowych, osobowości i kultury [...]. Normy kulturowe mogą zmieniać korelaty dobrostanu psychicznego” (Diener i in., 2004, s. 45-47).

\section{POWIAZZANIE ZADOWOLENIA Z ŻYCIA Z WYZNAWANYMI WARTOŚCIAMI, ORIENTACJAMI I KONTEKSTEM KULTUROWYM}

Zwróćmy najpierw uwagę na różnorodne związki zadowolenia z życia i poczucia szczęścia z problematyką wartości. Przede wszystkim należy podkreślić, że w tradycji filozoficznej realizację określonych wartości ujmowano jako warunek szczęścia. W tym ujęciu miarą szczęścia jest osiągnięcie tego, co warte jest starań. Przykładem może być stanowisko Arystotelesa i jego koncepcja cnót kardynalnych, do których zaliczał: mądrość, odwagę, miłość, sprawiedliwość, wstrzemięźliwość i duchowość. Znajdujemy także stanowiska podkreślające, że warunkiem autentycznego szczęścia jest życie zgodne z cnotami (Seligman, 2004). Szczęście - wiązane z poczuciem sensu życia - jest doświadczane dzięki realizacji priorytetowych wartości. W wielu systemach aksjologicznych szczęście jest z kolei traktowane jako jedna z wartości, zwykle wysoko lokowana w hierarchii (oczywiście występują różnice międzykulturowe w wartościowaniu szczęścia). Z jeszcze innej perspektywy system wartości człowieka jest ujmowany jako element różnic indywidualnych związanych z dobrostanem psychicznym lub wpływających na niego. Wyniki badań przeprowadzanych na gruncie psychologii empirycznej wskazują na związki między wyznawanymi wartościami a poczuciem szczęścia (Linley, Joseph, Seligman, 2004). 
Oczywiste jest też powiązanie problematyki dobrostanu z trzema wymiarami czasu: przeszłością, teraźniejszością i przyszłością (Tucholska, 2007). Z badań społecznych wynika, że na zadowolenie z życia wpływa przede wszystkim satysfakcja z własnych perspektyw na przyszłość (CBOS, 2014). Na ocenę szczęścia może mieć wpływ m.in. łatwość przywoływania wspomnień pozytywnych i negatywnych (Diener i in., 2004). Z kolei koncentracja na teraźniejszości, umiejętność życia chwilą mają szczególne znaczenie w hedonistycznym ujmowaniu szczęścia. Na związek dobrostanu psychicznego ze sposobem postrzegania czasu wskazują m.in. P. Zimbardo i J. Boyd (2009). Wspominają oni o zrównoważonej perspektywie postrzegania czasu, która otwiera różne drogi do szczęścia. Źródłem poczucia szczęścia może być odwoływanie się do przeszłości (wspominanie szczęśliwych wydarzeń, przeżywanie wdzięczności), do przyszłości (optymizm, formułowanie planów i celów życiowych) i koncentracja na teraźniejszości (smakowanie radości życia tu i teraz).

Problematyka dobrostanu psychicznego jest ujmowana w kontekście kulturowym. Dwa główne stanowiska teoretyczne wiążące kulturę i dobrostan to uniwersalizm oraz ujęcie relatywistyczne (Boski, 2010). Zwolennicy stanowiska uniwersalistycznego przyjmują, że w każdej kulturze dobrostan zależy od spełnienia uniwersalnych potrzeb: autonomii, kompetencji, relacji z innymi ludźmi. Ponadto stoją oni na stanowisku, iż większość ludzi w różnych kulturach czuje się umiarkowanie szczęśliwych, z wyjątkiem tych żyjących w skrajnie złych warunkach. Z kolei dla ujęcia relatywistycznego ważne są następujące przesłanki: (1) istnieją różnice kulturowe w wartościowaniu poczucia szczęścia; (2) występują, zależnie od kultury, różne sposoby odczuwania szczęścia i różne czynniki, które wywołują zadowolenie, np. szczęście jako stan spokoju i harmonii (kultury azjatyckie) versus szczęście jako wysoki poziom pobudzenia, podekscytowanie i radość (Amerykanie). W tym kontekście przywołuje się rozróżnienie kultur indywidualistycznych i kolektywistycznych, w których występują inne źródła zadowolenia i satysfakcji z życia.

Oczywiście istnieje także związek pomiędzy czynnikami kulturowym a doświadczaniem czasu i wartościami. Na przykład jeden z proponowanych podziałów kultur dokonywany jest w oparciu o kryteriu czasu i zgodnie z nim wyróżnia się: kultury monochroniczne versus polichroniczne, kultury czasu zegara versus kultury czasu wydarzeń, kultury zorientowane na przeszłość versus na teraźniejszość versus na przyszłość (Boski, 2010). Wartości także są ujmowane w kontekście kulturowym; na przykład zbiór podzielanych wartości stanowi ważny element psychologicznych wymiarów kultury, a jakość życia i dobrostan stanowi biegun jednego z wymiarów wartości kulturowych według R. Ingleharta (Ingelhart, Basanez, Moreno, 1998). 


\section{PREZENTACJA WYBRANYCH KONSTRUKTÓW TEORETYCZNYCH POWIĄZANYCH Z SATYSFAKCJĄ Z ŻYCIA}

Według psychologicznej koncepcji czasu Zimbardo (Zimbardo, Boyd, 2009), codzienny przepływ osobistych doświadczeń kształtowany jest przez charakterystyczną dla każdego z nas orientację czasową. Opieramy się na wspomnieniach (orientacja przeszłościowa), na spodziewanych konsekwencjach (orientacja na przyszłość) lub na bezpośrednio doświadczanej sytuacji (orientacja na teraźniejszość). Zwykle któraś z tych orientacji dominuje. Ludzie różnią się perspektywami czasowymi, tj. stopniem skupiania się na przeszłości, teraźniejszości bądź przyszłości. Nadmierna koncentracja na jednym wymiarze czasowym może być efektem wpływu wielu czynników o charakterze kulturowym, edukacyjnym, religijnym, związanym z pochodzeniem społecznym czy modelowaniem w rodzinie.

Kluczowe w teorii Zimbardo jest wyróżnienie przez niego sześciu podstawowych perspektyw postrzegania czasu, którymi są: przeszłość pozytywna (koncentracja na dobrych wspomnieniach), przeszłość negatywna (koncentracja na tym, co poszło źle), teraźniejszość hedonistyczna (życie chwilą i gonienie za przyjemnościami), teraźniejszość fatalistyczna (odbieranie tego, co się wydarza, jako nieuchronnego), przyszłość (uwzględnianie możliwych konsekwencji bieżących działań, planowanie) oraz przyszłość transcendentalna (uwzględnianie przyszłości wykraczającej poza własne życie, które wyrasta z przekonań religijnych lub „świeckiego” odwoływania się do potrzeb przyszłych pokoleń). Do kluczowych założeń psychologicznej teorii czasu sformułowanej przez Zimbardo można zaliczyć tezę, iż postrzeganie świata, sposób życia, podejmowane decyzje i działania są uwarunkowane przyjmowaną indywidualną perspektywą czasu. Nasze osobiste postrzeganie czasu jest wyuczone (nabyte) i ma w dużej mierze nieświadomy charakter. Stając się świadomym własnej perspektywy postrzegania czasu, można ją zmieniać, by kontrolować jakość swojego życia.

W kontekście związku orientacji temporalnych z dobrostanem psychicznym ustalono (Naeger, 2001; Zimbardo, Sword, Sword, 2013) optymalny profil perspektywy czasu, na który składają się: wysokie nasilenie przeszłościowo-pozytywnej perspektywy czasu, umiarkowanie wysokie nasilenie przyszłościowej i teraźniejszo-hedonistycznej perspektywy czasu oraz niskie nasilenie przeszłościowo-negatywnej i teraźniejszo-fatalistycznej perspektywy czasu (por. Tucholska, 2007). Zimbardo głosi potrzebę przyjmowania zrównoważonej, elastycznej perspektywy postrzegania czasu, która pozwala na „wybór najwłaściwszej dla danej sytuacji perspektywy postrzegania czasu [...]. W zależności od konkretnej sytuacji któraś z perspektyw czasu musi wysunąć się na prowadzenie” (Zimbardo, Boyd, 2009, s. 248). 
Popularnym narzędziem diagnozy orientacji czasowych jest kwestionariusz ZTPI (Zimbardo Time Perspective Inventory). W badaniach prowadzonych w populacji dorosłych Amerykanów (Zhang, Howell, Stolarski, 2013) okazało się, że osoby uzyskujące wysokie wyniki w skalach Przeszłość Pozytywna i Teraźniejszość Hedonistyczna kwestionariusza ZTPI charakteryzują się wyższym poczuciem satysfakcji z życia. Natomiast osoby uzyskujące wysokie wyniki w skali Przeszłość Negatywna charakteryzują się istotnie niższym poczuciem satysfakcji z życia. W innych badaniach (Boniwell, 2005), prowadzonych na próbie osób dorosłych w Stanach Zjednoczonych, uzyskano wyniki wskazujące, że poczucie satysfakcji z życia wiąże się pozytywnie z trzema wymiarami: Przeszłość Pozytywna, Teraźniejszość Hedonistyczna i Przyszłość, a negatywnie koreluje z Przeszłością Negatywną i Teraźniejszością Fatalistyczną. W ich świetle dobrostan psychiczny łączy się pozytywnie ze zrównoważoną perspektywą czasową. Okazała się ona również mocnym predyktorem subiektywnego dobrostanu w innych kontekstach kulturowych; na przykład w próbie młodych dorosłych z Tajwanu (Gao, 2011) oraz wśród studentów z Wielkiej Brytanii i Rosji (Boniwell, Osin, Liney, Ivanchenko, 2010) osoby o zrównoważonej perspektywie czasowej miały najwyższe wskaźniki poczucia satysfakcji z życia. Jak wykazali Zhang i współpracownicy (Zhang i in., 2013), posiadanie zrównoważonej perspektywy czasowej wiąże się z silnym poczuciem satysfakcji z życia, poczuciem szczęścia, pozytywnym afektem, poczuciem zaspokojenia potrzeb psychologicznych, autodeterminacją, witalnością, poczuciem wdzięczności.

Drugi, obok kategorii perspektyw czasowych, podstawowy konstrukt teoretyczny, który wiążemy z zagadnieniem satysfakcji z życia, to wartości, rozumiane za Schwartzem (1996) jako reprezentacje poznawcze (przekonania) pożądanych, ponadsytuacyjnych celów. Mają one strukturę hierarchiczną (różnią się ważnością) i spełniają rolę naczelnych zasad, które wpływają na zachowanie i dokonywane oceny. Obok tej formalnej charakterystyki wartości przeprowadzona została ich kategoryzacja na poziomie kulturowym i indywidualnym. Uniwersum wartości indywidualnych zostało podzielone na 10 typów tworzących kołowe kontinuum motywacyjne (Cieciuch, 2013). Wyróżnione wartości (lub typy wartości) to: przystosowanie, tradycja, życzliwość, uniwersalizm, kierowanie sobą, stymulacja, hedonizm, osiągnięcia, władza, bezpieczeństwo. Wartości te zostały sklasyfikowane do czterech podstawowych grup: otwartość na zmiany (kierowanie sobą, stymulacja) vs. zachowawczość (przystosowanie, tradycja, bezpieczeństwo), umacnianie siebie (osiągnięcia, władza) vs. przekraczanie siebie (życzliwość, uniwersalizm). Hedonizm pozostaje na pograniczu otwartości na zmiany i umacniania siebie. 
Badania, także o charakterze międzykulturowym, potwierdzają związek wartości i ich hierarchii z zadowoleniem z życia, jednakże ten związek miewa różny charakter. Jest wyraźnie silniejszy, jeśli chodzi o jego aspekt emocjonalny (odczuwanie szczęścia) niż poznawczy (odczuwanie zadowolenia jako rezultatu refleksji nad własnym życiem) (Sagiv, Schwartz, 2000). Wykazano, że wartości z zakresu kierowania sobą (autonomia, wolność, kreatywność) i dążenia do osiągnięć pozytywnie korelują z satysfakcją z życia (Boniwell, 2008). W badaniu przeprowadzonym przez A. Özdemira (2014) na grupie dorosłych w Turcji wskaźnik satysfakcji z życia, uzyskany w badaniu Skalą satysfakcji z życia (SWLS) Dienera, korelował negatywnie z wartością określaną w modelu Schwartza jako uniwersalizm, a pozytywnie z wartością tradycji. Badania przeprowadzone na międzynarodowej próbie osób z Nowej Zelandii, Wielkiej Brytanii, Kanady, Stanów Zjednoczonych i Australii ujawniły (Jarden, 2010), iż z kognitywnym aspektem dobrostanu wiąże się docenienie wartości samokierowania, stymulacji, hedonizmu, życzliwości, tradycji, konformizmu i bezpieczeństwa. Z kolei z badań przeprowadzonych przez N. Haslama, J. Whelan i B. Bastian (2009) na próbie amerykańskich studentów wynika, iż zachodzi powiązanie pomiędzy wartością, jaką jest stymulacja, a wynikami w skali SWLS Dienera. Związki te okazują się bardziej różnorodne i silniejsze, jeśli weźmie się pod uwagę mediacyjny charakter cech osobowości z modelu Wielkiej Piątki. W świetle wyników badań uzyskanych przez zespół kierowany przez Haslama cechy osobowości pełnią ważną funkcję pośredniczącą w związku pomiędzy wartościami a poczuciem dobrostanu.

\section{PROBLEM BADAWCZY I JEGO OSADZENIE W KONTEKŚCIE KULTUROWYM}

Główny problem badawczy stanowi pytanie, jaki jest związek między zadowoleniem z życia a perspektywami czasowymi oraz strukturą wartości indywidualnych w zróżnicowanych kulturowo populacjach, jakimi są Polacy i Ugandyjczycy. Czy zachodzą i jaki mają ewentualnie charakter różnice w poziomie satysfakcji z życia u studentów polskich i ugandyjskich? Jaka jest struktura perspektyw czasowych w tych dwóch grupach? Czy struktura cenionych przez nich wartości pozostaje podobna, czy może różni się znacząco?

Badania zdecydowano się przeprowadzić w dwóch wyraźnie zróżnicowanych ekonomicznie i kulturowo kontekstach - w Polsce i w Ugandzie. W tabeli 1 zaprezentowano zestawienie podstawowych wskaźników socjodemograficznych obrazujących skalę różnic między nimi. 
Tab. 1. Porównanie wybranych wskaźników socjodemograficznych dla populacji Polski i Ugandy

\begin{tabular}{lll}
\hline Wybrane wskaźniki socjodemograficzne & Polska & Uganda \\
\hline Produkt narodowy brutto per capita & 22 300 USD & 1 370 USD \\
\hline HDI & 0,834 (34 miejsce) & 0,484 (164 miejsce) \\
\hline Śmiertelność niemowląt na tysiąc urodzeń & 4,6 & 57 \\
\hline Oczekiwana długość życia bez względu na płeć & 70 & 59 \\
\hline Procent populacji poniżej 15 roku życia & 15 & 48 \\
\hline Procent populacji powyżej 65 roku życia & 14 & 2 \\
\hline Współczynnik płodności; liczba dzieci/kobieta & 1,2 & 5,9 \\
\hline Liczba osób zarażonych HIV & $0,027 \mathrm{mln}$ & $1,2 \mathrm{mln}$ \\
\hline
\end{tabular}

Źródło: Opracowanie własne na podstawie UNDP (2014) oraz World Population Data Sheet 2014 (Population Reference Bureau, 2014), statystyk Banku Światowego oraz WHO (2012).

Uganda jest państwem we wschodniej Afryce, położonym nad Jeziorem Wiktorii. Jest to jeden z najbiedniejszych krajów na świecie - w przeliczeniu na jednego mieszkańca ma jedno z najniższych PKB. Niemal 38\% ludności Ugandy żyje za mniej niż 1,25 USD dziennie. Prawie połowa populacji to dzieci, które mają mniej niż 15 lat, bardzo często osierocone przez rodziców (częstą przyczyną śmierci jest AIDS i inne choroby zakaźne). Zubożenie pozostaje głęboko zakorzenione zwłaszcza w obszarach wiejskich kraju, które są miejscem życia ponad 85\% mieszkańców Ugandy. Według indeksu HDI, który stanowi wskaźnik rozwoju społecznego, tj. zdrowia, skolaryzacji i dobrobytu materialnego, Uganda ze wskaźnikiem rzędu 0,484 w 2014 roku uplasowała się na 164. miejscu na 187 krajów. Do najważniejszych problemów Ugandyjczyków należą: brak dostępu do opieki medycznej i edukacji, liczne choroby układu pokarmowego, malaria wywoływana przez komary, duży odsetek osób zarażonych AIDS/HIV, niedożywienie, zwłaszcza dzieci, ograniczony dostęp do środków transportu.

\section{METODA}

\section{A) UCZESTNICY BADANIA}

Badanie przeprowadzono wśród studentów w dwóch istotnie różnych kontekstach kulturowych: w Polsce i w Ugandzie. Grupę polską stanowiło 58 studentów zarządzania na Uniwersytecie Jagiellońskim. Proporcje płci w grupie były następujące: 77\% kobiet i 23\% mężczyzn; średnia wieku stanowiła 20, 21 lat. Grupę ugandyjską 
stanowiło 47 studentów zarządzania z Uniwersytetu Makerere w Kampali i Fort Portal. Proporcje płci w grupie były następujące: 60\% kobiet i 40\% mężczyzn; średnia wieku to 20 lat.

\section{B) NARZĘDZIA BADAWCZE}

W badaniach zastosowano kwestionariusze psychologiczne w standardowej dla obu prób badawczych kolejności. Na zestaw składały się metody w wersji polskiej i anglojęzycznej, przeznaczonej do badania studentów w Ugandzie (gdzie język angielski jest językiem urzędowym). Wszystkie zastosowane metody charakteryzują się akceptowalnymi współczynnikami rzetelności i trafności pomiaru.

Skala satysfakcji z życia (Satisfaction with Live Scale - SWLS) w opracowaniu E. Dienera i współpracowników (Diener, Emmons, Larsen, Griffin, 1985) oraz w polskiej adaptacji Z. Juczyńskiego (2001) to metoda składająca się z pięciu twierdzeń (np. „Mam doskonałe warunki życia”), do których badani ustosunkowują się na siedmiostopniowej skali Likerta. W efekcie badania uzyskiwany jest jeden wskaźnik liczbowy (od 5 do 35 punktów) odzwierciedlający stopień przekonania osoby badanej o tym, iż życie jest dla niej satysfakcjonujące.

Kwestionariusz postrzegania czasu (Zimbardo Time Pespective InventoryZTPI) autorstwa P. Zimbardo i J. Boyda (1999) oraz w polskiej adaptacji N. Cybis, T. Rowińskiego i A. Przepiórki (2012). Itemy skali stanowią twierdzenia opisujące różne przekonania, preferencje oraz sposób wartościowania doświadczeń o charakterze temporalnym. Badani ustosunkowują się do nich na 5-stopniowej skali typu Likerta. Metoda pozwala na pomiar pięciu perspektyw czasowych. Dwie skale dotyczą pozytywnych i negatywnych aspektów orientacji na przeszłość (Przeszłość Pozytywna i Przeszłość Negatywna). Dwie inne skale - Teraźniejszość Fatalistyczna i Teraźniejszość Hedonistyczna - służą do diagnozy orientacji na zdarzenia aktualne. Piąta skala ZTPI, Przyszłość, pozwala na określenie gotowości ukierunkowania myślenia i działania na zdarzenia w przyszłości.

Kwestionariusz portretów PVQ autorstwa S. Schwartza i współpracowników (Schwartz, Melech, Lehmann, Burgess, Harris, 2001) oraz w polskiej adaptacji J. Cieciucha i Z. Zaleskiego (2011). Zastosowano wersje z 21 twierdzeniami (różne ze względu na płeć respondenta), w której osoba badana ocenia podobieństwo przedstawionego opisu do siebie (np. „Lubi podejmować ryzyko. Zawsze szuka przygód”) na sześciostopniowym kontinuum: od 1 - bardzo niepodobny(-na) do mnie do 6 - bardzo podobny(-na) do mnie. Badanie pozwala na pomiar stosunku do następujących wartości: (1) Przystosowanie, czyli posłuszeństwo, przestrzeganie norm społecznych, samodyscyplina, szacunek wobec starszych; (2) Tradycja, czyli 
akceptacja i szacunek wobec rytuałów i idei własnej kultury lub religii; (3) Życzliwość, czyli troska o dobro najbliższych, przyjaźń i miłość; (4) Uniwersalizm, czyli troska o dobro wszystkich ludzi, dbałość o ochronę środowiska, sprawiedliwość, mądrość, pokój; (5) Kierowanie sobą, czyli niezależność w myśleniu i działaniu, kreatywność, autonomia; (6) Stymulacja, czyli poszukiwanie nowości, dążenie do ekscytującego i urozmaiconego życia; (7) Hedonizm, czyli dążenie do przyjemności; (8) Osiągnięcia, czyli osobisty sukces, osiągnięty przez demonstrację kompetencji, zgodnie ze społecznymi standardami; (9) Władza, czyli status i prestiż społeczny, kontrola i dominacja nad innymi ludźmi oraz zasobami; (10) Bezpieczeństwo, czyli harmonia, porządek społeczny, bezpieczeństwo osobiste, rodziny i narodowe. Wynikiem jest średnia arytmetyczna z ocen przypisanych poszczególnym pozycjom. Im wyższy wynik, tym bardziej dana kategoria liczy się jako pryncypium w życiu człowieka. Wartości można poklasyfikować według dwóch wymiarów: otwartość na zmiany versus zachowawczość oraz umacnianie Ja versus przekraczanie Ja.

\section{WYNIKI BADAŃ}

\section{A) POZIOM MIERZONYCH ZMIENNYCH W GRUPIE STUDENTÓW POLSKICH I UGANDYJSKICH}

W pierwszym etapie analizy dokonano porównań wyników uzyskanych przez grupy polskich i ugandyjskich studentów w zakresie poziomu satysfakcji z życia, profilu perspektyw postrzegania czasu i profilu wartości podstawowych. Dalsze analizy będą mieć na celu zbadanie związków pomiędzy satysfakcją z życia a perspektywami czasowymi i wartościami w obydwu grupach narodowych.

Pomiar satysfakcji życiowej za pomocą skali SWLS wskazuje na umiarkowane zadowolenie z życia w obydwu grupach badanych. Jeśli uśrednimy wynik dla mężczyzn i kobiet, to poziom zadowolenie okazuje się podobny w grupie studentów polskich $(M=21,98 ; S D=5,42)$ i ugandyjskich $(M=21,00 ; S D=6,01), F(1,103)=0,78$; $\mathrm{p}=0,37$. Jednak uwzględniając porównania międzypłciowe okazuje się, że w grupie studentów ugandyjskich kobiety ( $\mathrm{M}=23,00, \mathrm{SD}=6,06)$ charakteryzują się wyższym poziomem zadowolenia z życia niż mężczyźni ( $M=18.05, S D=4,66 ; p<0,01)$. Według klucza przyjętego przez Dienera (Diener i in., 1985) wynik uzyskany przez ugandyjskie kobiety wskazuje na umiarkowane zadowolenie z życia (podobnie jak w grupie studentów polskich), natomiast średni wynik uzyskany przez mężczyzn z tego kraju wskazuje na ich umiarkowane niezadowolenie. Opisywane zależności zobrazowano na wykresie 1. 


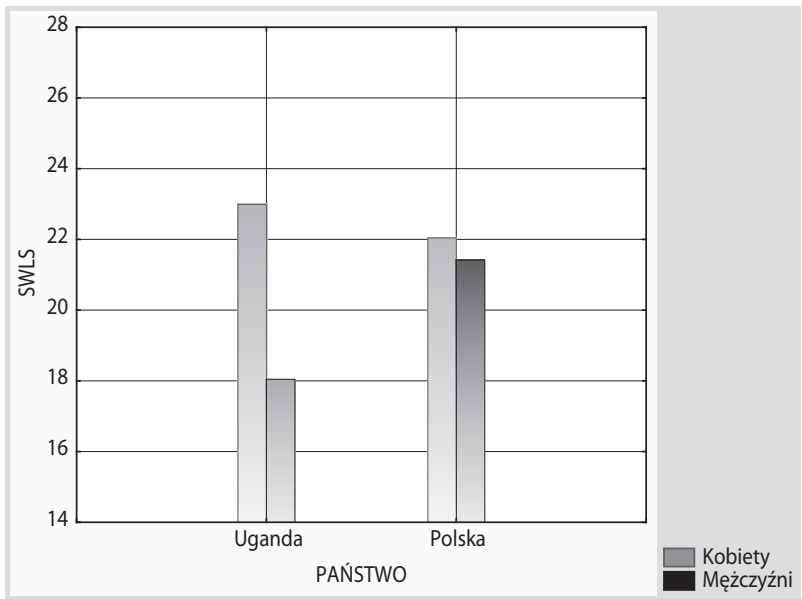

Wykres 1. Zadowolenie z życia (SWLS) w grupie ugandyjskich i polskich studentów w zależności od płci

Źródło: Opracowanie własne.

Kolejna badana zmienna to orientacje czasowe. Za pomocą analizy wariancji porównano perspektywy postrzegania czasu w grupie studentów polskich i ugandyjskich. Wystąpił efekt interakcji kraju i perspektyw czasowych $(\mathrm{F}(4,420)=9,36$; $\mathrm{p}<0,001)$. Ilustruje to wykres 2 .

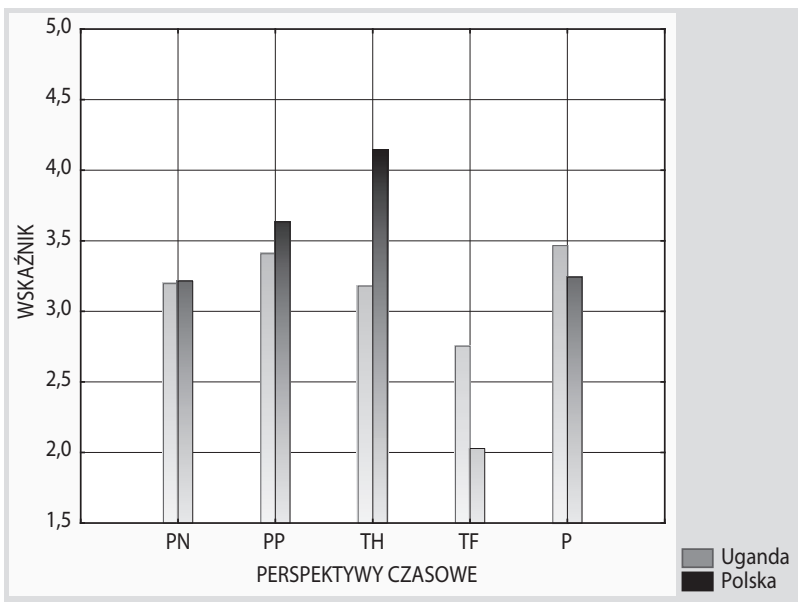

Wykres 2. Perspektywy postrzegania czasu w grupie studentów polskich i ugandyjskich

Skróty: PN - przeszłość negatywna, PP - przeszłość pozytywna, TH - teraźniejszość hedonistyczna, TF - teraźniejszość fatalistyczna, P - przyszłość

Źródło: Opracowanie własne. 
W grupie polskich studentów najwyraźniej zaznaczona jest perspektywa Teraźniejsza Hedonistyczna, a na drugim miejscu Przeszłość Pozytywna, która także jest istotnie wyższa od pozostałych orientacji czasowych. Istotnie najniższy wynik, w porównaniu z każdą inną perspektywą czasową, badana grupa Polaków uzyskała w skali Teraźniejszość Fatalistyczna. Z kolei orientacja Przyszłościowa ma istotnie wyższy poziom od Przeszłości Negatywnej $(F(1,59)=9,89 ; p<0,01)$.

Także w grupie Ugandyjczyków wskaźnik Teraźniejszości Fatalistycznej jest na najniższym poziomie w porównaniu z każdą inną perspektywą czasową. Przeszłość Negatywna ma istotnie niższy poziom od Przeszłości Pozytywnej $(\mathrm{F}(1,46)=8,82$; $\mathrm{p}<0,01)$ i od orientacji Przyszłościowej $(\mathrm{F}(1,46)=8,54 ; \mathrm{p}<0,01)$. Natomiast - inaczej niż w grupie studentów polskich - Teraźniejszość Hedonistyczna w tej grupie ma średni poziom; istotnie niższy od Przeszłości Pozytywnej $(F(1,46)=8,05 ; p<0,01)$ i od orientacji Przyszłościowej $(\mathrm{F}(1,46)=9,37$; $\mathrm{p}<0,01)$.

Porównania między badanymi narodowościami wskazują na dwa charakterystyczne wyniki: studenci polscy cechują się istotnie wyższym od grupy ugandyjskiej poziomem Teraźniejszości Hedonistycznej $(F(1,103)=29,64 ; p<0,001)$, z kolei studenci z Ugandy uzyskali istotnie wyższy od polskiej grupy poziom Teraźniejszości Fatalistycznej $(\mathrm{F}(1,103)=7,08 ; \mathrm{p}<0,01)$.

Wyniki badania Kwestionariuszem Portretów PVQ pozwalają stwierdzić, iż w polskiej grupie najbardziej cenione są trzy typy wartości: życzliwość, kierowanie sobą i osiągnięcia. Trzeba podkreślić, że nie ma między nimi istotnej różnicy statystycznej, natomiast lokują się istotnie wyżej niż pozostałe wartości. Najniżej w hierarchii wartości studentów z Polski znalazły są tradycja i władza. W grupie ugandyjskiej najwyżej ceniona jest życzliwość, a następnie uniwersalizm i kierowanie sobą. Hedonizm to typ wartości, który jest zdecydowanie najniżej lokowany spośród wszystkich dziesięciu typów wartości przez studentów z Ugandy.

\section{B) ZADOWOLENIE Z ŻYCIA I JEGO ZWIĄZEK Z PERSPEKTYWAMI CZASOWYMI A KONTEKST KULTUROWY}

Jaki jest związek między poszczególnymi orientacjami czasowymi a satysfakcją z życia w obydwu grupach badanych? Tabela 2 zawiera wyniki analizy korelacji pomiędzy wspomnianymi zmiennymi.

Analiza uzyskanych wyników wskazuje, że satysfakcja z życia w grupie polskiej ma związek z jednym wymiarem czasu - z przeszłością. Im większa orientacja na Przeszłość Pozytywną, tym większy poziom satysfakcji z życia. Odwrotnie jest w przypadku Przeszłości Negatywnej - ta perspektywa postrzegania czasu pozostaje w negatywnym związku z zadowoleniem z życia. Natomiast w grupie 
ugandyjskiej nie wystąpiły istotne statystycznie korelacje między perspektywami czasowymi a zadowoleniem z życia.

Tab. 2. Wskaźniki korelacji r Pearsona pomiędzy wynikami w skalach SWLS i ZTPI w grupie polskiej i ugandyjskiej

\begin{tabular}{|c|c|c|c|c|c|}
\hline${ }_{\text {SWLS }}$ ZTPI & $\begin{array}{l}\text { Przeszłość } \\
\text { Negatywna }\end{array}$ & $\begin{array}{l}\text { Przeszłość } \\
\text { Pozytywna }\end{array}$ & $\begin{array}{l}\text { Teraźniejszość } \\
\text { Hedonistyczna }\end{array}$ & $\begin{array}{l}\text { Teraźniejszość } \\
\text { Fatalistyczna }\end{array}$ & Przyszłość \\
\hline $\begin{array}{l}\text { Satysfakcja } \\
\text { z życia (Polska) }\end{array}$ & $-0,490 *$ & $0,402^{*}$ & 0,234 & $-0,226$ & 0,186 \\
\hline $\begin{array}{l}\text { Satysfakcja z ży- } \\
\text { cia (Uganda) }\end{array}$ & $-0,208$ & 0,004 & 0,025 & $-0,033$ & 0,213 \\
\hline
\end{tabular}

Uwaga: Asteryskiem (*) znaczono współczynniki korelacji istotne na poziomie p<0,05.

Źródło: Opracowanie własne.

\section{C) ZADOWOLENIE Z ŻYCIA I JEGO ZWIĄZEK Z WARTOŚCIAMI A KONTEKST KULTUROWY}

Szukając odpowiedzi na pytanie, jaka jest relacja między preferencją określonych wartości a zadowoleniem z życia, zbadaliśmy korelacje $r$ Pearsona pomiędzy zmiennymi mierzonymi skalą SWLS i PVQ.

Tab. 3. Macierz korelacji $r$ Pearsona pomiędzy z wynikami w skalach SWLS i PVQ w grupie polskiej i ugandyjskiej

\begin{tabular}{|c|c|c|c|c|c|c|c|c|c|c|}
\hline SWLS & 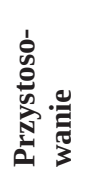 & 莺 & : & : & نَّ & 苞 & 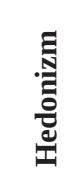 & 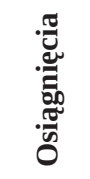 & $\frac{\frac{\pi}{2}}{\frac{\pi}{3}}$ & 宽 \\
\hline $\begin{array}{l}\text { Satysfakcja } \\
\text { z życia } \\
\text { (Polska) }\end{array}$ & 0,189 & $0,26^{*}$ & $0,52^{*}$ & 0,206 & $0,35^{*}$ & 0,193 & 0,068 & $0,30 *$ & 0,174 & 0,213 \\
\hline $\begin{array}{l}\text { Satysfakcja } \\
\text { z życia } \\
\text { (Uganda) }\end{array}$ & 0,191 & 0,019 & 0,142 & $-0,119$ & $0,39 *$ & $-0,01$ & 0,128 & 0,058 & $0,316^{*}$ & 0,011 \\
\hline
\end{tabular}

Uwaga: Asteryskiem (*) znaczono współczynniki korelacji istotne na poziomie $\mathrm{p}<0,05$.

Źródło: Opracowanie własne.

Satysfakcja z życia u Polaków koreluje z wyznawaniem wartości tradycji i życzliwości (należących do grupy wartości opisywanej jako przekraczanie siebie), osiągnięć i kierowania sobą. W grupie ugandyjskiej satysfakcja z życia jest 
mocno powiązana z wartością kierowania sobą i z wartością władzy. Jak widać, w obydwu grupach zadowolenie z życia jest pozytywnie skorelowane z wartością kierowania sobą.

\section{PODSUMOWANIE I DYSKUSJA WYNIKÓW BADAŃ WŁASNYCH}

Nasze badania dotyczyły poznawczego aspektu dobrostanu psychicznego, czyli zadowolenia z życia, które ujmowaliśmy w związku z perspektywami postrzegania czasu i hierarchią wartości w dwóch kontekstach kulturowych: ugandyjskim i polskim. Ogólny wskaźnik zadowolenia - przy uśrednionych wynikach dla mężczyzn i kobiet - wskazuje na umiarkowane zadowolenie z życia w obydwu grupach badanych. Podobny poziom zadowolenia w grupie polskich i ugandyjskich studentów oznacza, że obiektywne warunki życia nie odgrywają roli czynnika rozstrzygającego. Potwierdza to dotychczasowe badania wskazujące, iż większość ludzi w różnych kulturach czuje się umiarkowanie szczęśliwych, o ile nie żyją w skrajnie złych warunkach (Diener i in., 2004). Trzeba jednak podkreślić, że w grupie ugandyjskiej wskaźnik zadowolenia u kobiet był istotnie wyższy niż u mężczyzn.

Na otrzymany wynik można spojrzeć odwołując się do kontekstowych teorii dobrostanu, które m.in. wskazują na rolę porównań w ocenie własnego życia. Do takich teorii należy koncepcja wielorakich rozbieżności sformułowana przez Michalosa (1985), zgodnie z którą zakłada się, że ocena własnego życia bazuje na różnych porównaniach: z innymi ludźmi, z własną przeszłością i z własnymi oczekiwaniami. Ludzie są między innymi wtedy zadowoleni z życia, gdy wiedzie im się lepiej niż innym, lepiej niż w przeszłości oraz tak dobrze lub lepiej niż oczekiwali i gdy mają nadzieję na lepszą przyszłość. Wydaje się, że takie kryteria oceny własnego życia mogą być ważnym źródłem zadowolenia w grupie ugandyjskiej. Biorąc pod uwagę niski wskaźnik skolaryzacji (odsetek osób uczących się w szkołach średnich wynosi ok. 18\%, a liczba osób, które ukończyły w Ugandzie szkołę wyższą stanowi nieznaczny odsetek całego społeczeństwa), można powiedzieć, że badana grupa młodych Ugandyjek i Ugandyjczyków należy do osób uprzywilejowanych w stratyfikacji społecznej ${ }^{4}$. Bowiem tylko nieliczni w tym kraju osiągają tak wysoki poziom wykształcenia i co się z tym wiąże, mają zdecydowanie większe szanse na znalezienie dobrej pracy i zajmowanie prestiżowych

4 Dane na podstawie The Republic of Uganda Ministry of Education, Science, Technology and Sports (2011). 
stanowisk ${ }^{5}$. Osoby studiujące w Ugandzie mieszkają w zróżnicowanych, czasem bardzo trudnych warunkach mieszkaniowych, najczęściej borykają się z tymi samymi trudnościami co wszyscy Ugandyjczycy, jednak ta specyficzna grupa w jakimś sensie w przyszłości może tworzyć elitę tego kraju. Zostali wybrani jako najlepsi uczniowie, aby osiągnąć lepszy poziom życia. Bardzo często kosztami ich edukacji obciążona jest cała rodzina oraz liczni darczyńcy. Po ukończeniu szkoły i zdobyciu wykształcenia mogą spłacać dług w postaci wsparcia materialnego dla społeczności, z której się wywodzą.

Kryteria oceny własnego życia, związane z porównywaniem swojej sytuacji z innymi ludźmi, z własnymi oczekiwaniami, z przeszłością, wydają się stanowić silniejszy predyktor zadowolenia z życia u ugandyjskich kobiet niż mężczyzn. Wynika to z wielu uwarunkowań społeczno-kulturowych. Sytuacja ugandyjskich kobiet jest szczególnie trudna na prowincji, terenach znacznie odległych od stolicy państwa, Kampali. Chociaż Konstytucja Ugandy zawiera zapisy gwarantujące równouprawnienie kobiet i ich prawo do edukacji przez całe życie, podejmowanie obowiązków związanych z wczesnym zamążpójściem i wychowywaniem licznego potomstwa powoduje niejednokrotnie wykluczenie kobiet z edukacji formalnej ${ }^{6}$. Należy także uwzględnić, że Ugandyjki, szczególnie na zachodzie kraju, żyją w społeczeństwie patriarchalnym z wykształconą postawą submisyjną. Oprócz wykonywania licznych prac domowych i opieki nad dziećmi muszą ciężko pracować w polu. W kontaktach społecznych przeważnie zwracają się do innych osób w sposób bardzo cichy, często przyklękając na kolana z pochyloną głową. W tych regionach to mężczyźni podejmują decyzje za wszystkich członków rodziny. Istotny problem stanowią również ciężkie warunki mieszkaniowe, brak środków do życia i możliwości samodzielnego zaspokojenia podstawowych potrzeb. Dlatego zdobycie wyższego wykształcenia stanowi dla kobiet szansę na podjęcia pracy i zmianę niekorzystnej sytuacji ich rodzin (Kawula, 2014).

Interesujące wydają się uzyskane przez nas wyniki dotyczące perspektyw postrzegania czasu. W grupie polskich studentów dominuje Teraźniejszość Hedonistyczna i Przeszłość Pozytywna, a najniższy wynik wystąpił w Teraźniejszości Fatalistycznej. Także w grupie ugandyjskiej Teraźniejszość Fatalistyczna znalazła się na niższym poziomie od wszystkich innych perspektyw czasowych. Porów-

5 Aż 97\% ugandyjskich dzieci rozpoczyna naukę szkolną, wykształcenie podstawowe uzyskuje już tylko 32\% z nich. Liczba osób, które ukończyły w Ugandzie szkołę wyższą, stanowi nieznaczny odsetek całego społeczeństwa. Całkowita liczba zarejestrowanych studentów w Ugandzie w 2013 roku wynosiła 201376 (113 688 mężczyzn i 87572 kobiety) we wszystkich uczelniach w całym kraju 56\% stanowili mężczyźni (Openjuru, 2010, s. 27).

6 Konstytucja Ugandy z 1995, art. 32 (1), 33 ust. 1,2,3,4. 
nanie badanych grup narodowych pokazuje, że polscy studenci mają istotnie wyższy od grupy ugandyjskiej poziom Teraźniejszości Hedonistycznej, a istotnie niższy poziom Teraźniejszości Fatalistycznej. Jak zauważa Zimbardo (Zimbardo, Boyd, 2009), szczęście można odnaleźć w każdym wymiarze czasu; przeszłości, teraźnejszości i przyszłości. Rozważając związek perspektyw postrzegania czasu z zadowoleniem z życia można skonstatować, że uzyskany w naszych w badaniach profil orientacji czasowych sprzyja zadowoleniu z życia; bowiem dwie orientacje, które we wszystkich dotychczasowych badaniach negatywnie korelują z dobrostanem, tj. Przeszłość Negatywna i Teraźniejszość Fatalistyczna, uzyskały istotnie niższe wyniki od Przeszłości Pozytywnej i orientacji Przyszłościowej. Jednak okazało się, że w grupie polskich studentów perspektywy postrzegania czasu pozostają w silniejszym związku z satysfakcją z życia. Ten związek zadowolenia z perspektywą postrzegania czasu dotyczy wymiaru przeszłości - u Polaków Przeszłość Pozytywna koreluje pozytywnie, a Przeszłość Negatywna koreluje negatywnie z satysfakcją z życia.

Badania preferencji wartości wskazują na dosyć podobny wzór wyników w obydwu grupach z wyższym nasileniem danych wartości u Ugandyjczyków niż Polaków. Ta prawidłowość nie dotyczy tylko hedonizmu - jest to typ wartości, który przez studentów z Ugandy jest zdecydowanie najniżej lokowany spośród wszystkich dziesięciu typów wartości i ma istotnie mniejsze znaczenie niż w grupie polskiej. Jak zauważono we wprowadzeniu teoretycznym, poszukiwanie związku wartości z zadowoleniem z życia przynosiło różne wyniki. Jednak często uzyskiwano pozytywny związek zadowolenia z wartością kierowania sobą i osiągnięciami. Zostało to potwierdzone w naszych badaniach; w polskiej grupie pozytywnie korelują z zadowoleniem z życia takie wartości, jak: kierowanie sobą, osiągnięcia, tradycja, życzliwość. Co interesujące, trzy z tych wartości (kierowanie sobą, osiągnięcia, życzliwość) znalazły się najwyżej w hierarchii badanych wartości. W grupie ugandyjskiej wystąpił istotny związek zadowolenia z życia z wartością kierowania sobą i z władzą. Okazuje się zatem, że w obydwu grupach badanych im większą wartość przypisuje się kierowaniu sobą (niezależność w myśleniu, działaniu i wyborach; twórczość; wolność), tym większe zadowolenie z życia (Cieciuch, 2013).

Warto także zwrócić uwagę na małą rolę hedonizmu w poznawczym aspekcie dobrostanu. W grupie polskiej wystąpiła istotnie silniejsza orientacja czasowa na Teraźniejszość Hedonistyczną oraz istotnie wyższa preferencja wartości hedonizmu niż w grupie ugandyjskiej. Jednak nie miało to wpływu na różnicę w zadowoleniu z życia, bowiem w obydwu grupach te zmienne, zarówno orientacja na Teraźniejszość Hedonistyczną, jak preferowanie wartości hedonizmu, nie korelowały z satysfakcją z życia. 
Trzeba podkreślić ograniczenie przeprowadzonych badań. Uzyskane rezultaty nie mogą być generalizowane na populacje obydwu krajów, co wiąże się zarówno z liczbą badanych, jak i specyficzną kategorią uczestników badań (studenci). Jednakże wybór jednolitej grupy badanych pozwala uzyskać pewien wgląd w przeżywanie zadowolenia z życia przez te konkretne grupy oraz wgląd w jego związek z orientacjami czasowymi i strukturą wartości indywidualnych.

\section{Literatura:}

Boniwell, I. (2008). Positive psychology in a nutshell: A balanced introduction to the science of optimal functioning. London: PWBC.

Boniwell, I. (2005). Beyond time management: how the latest research on time perspective and perceived time use can assist clients with time related concerns. International Journal of Evidence Based Coaching and Mentoring, 3 (2), s. 61-74.

Boniwell, I., Osin, E., Liney, P.A., Ivanchenko, G.V. (2010). A question of balance: Time perspective and well-being in British and Russian samples. Journal of Positive Psychology: Dedicated to furthering research and promoting good practice, 5 (1), s. 24-40.

Boski, P. (2010). Kulturowe ramy zachowań społecznych. Warszawa: Wydawnictwo Naukowe PWN.

CBOS (2014). Komunikat badań: Polacy o swoim sześciu, pechu i zadowoleniu z życia. Warszawa: Fundacja Centrum Badania Opinii Społecznej.

Cieciuch, J. (2013). Kształtowanie się struktury i hierarchii wartości od dzieciństwa do wczesnej dorosłości. Warszawa: Wydawnictwo Liberi Libri.

Cieciuch, J., Zaleski, Z. (2011). Polska adaptacja Portretowego Kwestionariusza Wartości Shaloma Schwartza. Czasopismo Psychologiczne, 17 (2), s. 251-262.

Cieciuch, J. (2013). Pomiar wartości w zmodyfikowanym modelu Shaloma Schwartza. Psychologia Społeczna, tom 8, 1 (24), s. 22-41.

Cybis, N., Rowiński, T., Przepiórka, A. (2010). Development of the Polish version of Zimbardo Time Perspective Inventory. First International Conference on Time Perspective, Coimbra, Portugal.

Diener, E., Biswas-Diener, R.B. (2010). Szczęście: odkrywanie bogactwa psychicznego. Sopot: Wydawnictwo Smak Słowa.

Diener, E., Emmons, R., Larsen, R., Griffin, S. (1985). The Satisfaction With Life Scale. Journal of Personality Assessment, 49 (1), s. 71-75.

Diener, E., Lucas, R.E., Oishi, S. (2004). Dobrostan psychiczny. Nauka o szczęściu i zadowoleniu z życia. W: J. Czapiński (red.), Psychologia pozytywna (s. 35-50). Warszawa: Wydawnictwo Naukowe PWN.

Gao, Y. (2011). Time Perspective and Life Satisfaction Among Young Adults in Taiwan. Social Behavior and Personality: An International Journal, 39 (6), s. 729-736.

Hagerty, M., Veenhoven, R. (2003). Wealth and happiness revisited: Growing wealth of nations does go with greater happiness. Social Indicators Research, 64, s. 1-27. 
Haslam, N., Whelan, J., Bastian, B. (2009). Big Five traits mediate associations between values and subjective well-being. Personality and Individual Differences, 46, s. 40-42.

Hofer, J., Chasiotis, A., Campos, D. (2006). Congruence between social values and implicit motives: Effects on life satisfaction across three cultures. European Journal of Personality, 20, s. 305-324.

UNDP (2013). Human Development Report 2014. Tokio: HDRO.

Ingelhart, R., Basanez, M., Moreno, A. (1998). Human values and beliefs. A cross-cultural sourcebook. Ann Arbor, MI: University of Michigan Press.

Jarden, A. (2010). Relationships between personal values, and depressed mood and subjective wellbeing. Thesis submitted for the degree of Doctor of Philosophy at the University of Canterbury. Christchurch.

Juczyński, Z. (2001). Narzędzia pomiaru w promocji i psychologii zdrowia. Warszawa: Pracownia Testów Psychologicznych.

Kawula, A. (2014). Uwarunkowania społeczno-kulturowe edukacji zawodowej kobiet w Ugandzie. Edukacja Ustawiczna Dorosłych, 1 (84), s. 27-38.

Linley, P., Joseph, S., Seligman, M. (2004). Positive Psychology in Practice. New York: John Wiley \& Sons, Inc.

Maciuszek, J. (2014). Szczęściarz i pechowiec - wyrok losu czy indywidualne predyspozycje? W: A.W. Wudarski (red.), W poszukiwaniu jakości życia. Studium interdyscyplinarne (s. 25-38). Częstochowa-Frankfurt nad Odrą-Osnabrück: Akademia im. Jana Długosza.

Michalos, A. (1985). Multiple Discrepancies Theory. Social Indicators Research, 16, s. 347-413.

Naeger, M. (2001). Temporal, Perspectives, Dispositional Styles, and Subjective Well-Being. Masters Theses \& Specialist Projects. Paper 690. Pobrane z: http://digitalcommons. wku.edu/cgi/viewcontent.cgi?article=1693\&context=these.

Oishi, S., Diener, E., Suh, E., Lucas, R. (1999). Value as a moderator in subjective well-being. Journal of Personality, 67 (1), s. 157-184.

Openjuru, G.L. (2010). Government education policies and the problem of early school leaving: the case of Uganda. W: J. Zeelen, J. Van der Linden, D. Nampota, M. Ngabirano (red.), The Burden of Educational Exclusion. Understanding and Challenging Early School Leaving in Africa (s. 22-47). Rotterdam: Sense Publishers.

Özdemir, A. (2014). The relationship between value domains and subjective well-being of employees: Evidence from Turkey. International Journal of Human Resource Studies, 4. Pobrane z: http://www.macrothink.org/journal/index.php/ijhrs/article/ viewFile/6384/6153.

Population Reference Bureau (2014). World Population Data Sheet 2014. Pobrane z: http:// www.prb.org/pdf14/2014-world-population-data-sheet_eng.pdf.

Sagiv, L., Schwartz, S. (2000). Value priorities and subjective well-being: direct relations and congruity effects. European Journal of Social Psychology, 30, s. 177-198.

Schwartz, S. (1996). Value priorities and behavior. W: C. Seligman, J. Olson, P. Zanna (red.), The psychology of values: The Obtario Symposium (s. 1-24). Mahwah, NJ: Lawrence Erlbaum.

Schwartz, S., Melech, G., Lehmann, A., Burgess, S., Harris, M. (2001). Extending the 
cross-cultural validity of the theory of basic human values with a different method of measurement. Journal of Cross-Cultural Psychology, 32 (5), s. 519-542.

Seligman, M. (2004). Prawdziwe szczęście. Poznań: Media Rodzina.

Stolarski, M., Matthews, M., Postek, S., Zimbardo, P., Bitner, J. (2013). How We Feel is a Matter of Time: Relationships Between Time Perspectives and Mood. Journal of Happiness Studies, 15 (4). DOI 10.1007/s10902-013-9450-y.

Tatarkiewicz, W. (2012). O szczęściu. Warszawa: Wydawnictwo Naukowe PWN.

Triandis, H. (2004). Kultura a subiektywny dobrostan. W: J. Czapiński (red.), Psychologia pozytywna. Warszawa: Wydawnictwo Naukowe PWN.

Tucholska, K. (2007). Kompetencje temporalne jako wyznacznik dobrego funkcjonowania. Lublin: TN KUL.

The Republic of Uganda Ministry of Education, Science, Technology and Sports (2011). Uganda Education Statistical Abstract. Pobrane z: http://www.education.go.ug/files/ downloads/Education\%20Abstract\%202011.pdf.

Watson, D., Clark, L., Tellegen, A. (1988). Development and validation of brief measures of positive and negative affect: The PANAS scales. Journal of Personality and Social Psychology, 54 (6), s. 1063-1070.

Zhang, J., Howell, R., Stolarski, M. (2013). Comparing Three Methods to Measure a Balanced Time Perspective: The Relationship Between a Balanced Time Perspective and Subjective Well-Being. Journal of Happiness Studies, 14, s. 169-184.

Zimbardo, P., Boyd, J. (1999). Putting Time in Perspective: A Valid, Reliable Individual-Differences Metric. Journal of Personality and Social Psychology, 77 (6), s. 1271-1288. Zimbardo, P., Boyd, J. (2009). Paradoks czasu. Warszawa: Wydawnictwo Naukowe PWN. Zimbardo, P., Sword, R., Sword, R. (2013). Siła czasu. Warszawa: Wydawnictwo Naukowe PWN. 